\title{
Makna Fonemik dalam Semantik Arab: Ontologi, Epistemologi, Aksiologi
}

\author{
Fharis Romanda* \\ Universitas Islam Negeri (UIN) Sunan Kalijaga, Yogyakarta, Indonesia
}

\section{The Phonemic Meaning in Arabic Semantics: Ontology, Epistemology, Axiology}

\section{E-Mail Address}

20201011007@student.uin-

suka.ac.id

*Corresponding Author

\begin{abstract}
This study aims to provide an understanding of the phonemic meaning (dalälah șawtìyah) in Arabic semantics. To provide an understanding related to dalālah sawtîyah, this study carries out its research based on a philosophical framework of thought consisting of ontology, epistemology, and axiology. It can be concluded that the discussion of this research broadly discusses the ontology or nature of sawtīyah, its epistemology or method, and the axiology or function of the branch of the discussion of semantics. This research is based on a literature review. In analyzing data obtained from the literature review, this study used qualitative methods. This research has revealed the nature of sound, how sound works, and the function of each sound method in the Arabic interpretation process. This research concludes that the sound in the dalälab sawtīyah has an important role in determining meaning in all language structures starting from Arabic words, phrases, and sentences. The method of sound work in giving meaning to Arabic can be in the form of differences in phoneme sounds, sound stress (al-nabr) in syllables or words, as well as intonation (al-tanghim) that occurs in a phrase or sentence.
\end{abstract}

Keywords

Phoneme;

nabr;

tanghim;

semantic

\section{Pendahuluan}

Manusia sebagai makhluk sosial selalu membutuhkan manusia lainnya untuk memenuhi kebutuhan hariannya. Beranjak dari sebuah kebutuhan yang dimiliki manusia terhadap manusia lainnya, maka manusia akan menemui dan mengungkapkan maksudnya kepada manusia lainnya. Dengan begitu, akan selalu terjadi sebuah interaksi sosial antarmanusia. Dalam proses interaksi tersebut, manusia membutuhkan media komunikasi untuk menyampaikan maksud dan keinginannya kepada manusia lainnya supaya kebutuhannya dapat terpenuhi. Untuk itu, manusia menggunakan bahasa sebagai media komunikasi dan interaksi dalam kehidupan sosialnya. Oleh karena interaksi sosial yang dilakukan manusia dengan lainnya, bahasa dalam pengertiannya dapat diartikan sebagai bunyi-bunyi yang digunakan suatu masyarakat untuk mengungkapkan perasaannya (Ibn Jinnī, 1952).

Sebagai media komunikasi dalam interaksi sosial, bahasa memiliki kapasitas yang begitu penting dalam kehidupan manusia. Dengan bahasalah manusia dapat dibedakan dari seekor hewan (Fromkin et al., 2017). Di sisi lain, bahasa juga telah menjadi sebuah objek kajian ilmiah. Bahasa dapat dikaji 
melalui komponen-komponen yang menyusunnya mulai dari bunyi, kata, struktur, dan maknanya. Para ilmuan atau ahli bahasa dengan peran ilmu filsafat telah mengelompokkan kajian-kajian tersebut secara mandiri dan memberikan penamaan masing-masing untuk setiap pembahasannya.

Bunyi sebagai salah satu komponen dari bahasa juga telah menjadi objek kajian tersendiri yang disebut dengan ilmu fonologi. Ilmu fonologi merupakan cabang dari kajian ilmu linguistik yang membahas dan menelusuri tentang bagaimana cara-cara suara atau bunyi diucapkan dan digunakan secara sistematis sehingga membentuk kata-kata dan ucapan (Katamba, 1989). Dengn kata lain, kajian fonologi dapat dikategorikan sebagai kajian fungsional dari bunyi. Selain itu, bunyi juga memiliki keterkaitan kuat dengan cabang ilmu linguistik lainnya, yaitu ilmu semantik. Dalam ranah kajian ilmu semantik, bunyi telah mendapatkan perhatian khusus oleh para ilmuan dan ahli bahasa. Hal tersebut dikarenakan suara dianggap memilki pengaruh penting dalam pemaknaan bahasa.

Bahasa Arab, layaknya bahasa lainnya di seluruh dunia, juga telah memainkan dua peran penting dalam kehidupan manusia, yaitu sebagai media komunikasi dan interaksi sosial, serta sebagai objek kajian keilmuan yang telah diteliti sejak ribuan tahun yang lalu. Sebagai sebuah objek kajian, bahasa Arab telah melahirkan banyak karya dalam berbagai bidang dan unsur dimensi bahasa mulai dari kajian terkait fonologi hingga konteks gramatikal. Pada konteks penelitian bahasa, para peneliti bahasa Arab pada zaman modern sepeti Aḥmad Mukhtār 'Umar dan Ibrāhīm Anīs juga telah melakukan pengkajian terkait fonologi dan ilmu semantik dalam bahasa Arab. Dalam istilah bahasa Arab, kajian ilmu fonologi disebut dengan 'ilm al-așwāt, sedangkan ilmu semantik dinamakan dalālah șawțīyah.

Lebih lanjut, tulisan ini membahas salah satu bagian dari ilmu semantik Arab. Titik fokus pada kajian penelitian ini adalah pembahasan tentang peran bunyi sebagai cabang dari ilmu semantik Arab. Pada proses pengkajiannya, semantik dan fonologi berkolaborasi dalam memaparkan peran bunyi dalam pemaknaan bahasa. Tulisan ini menyajikan kajian dalälah șawtīyah atau makna fonemik dalam ilmu semantik bahasa Arab dengan merujuk pada kerangka cara berfikir dalam filsafat ilmu yang meliputi ontologi, epistemologi, dan aksiologi. Kajian tentang dalālah șawțīyah dalam tulisan ini dimaksudkan agar para pemerhati bahasa lebih mudah dalam memahami hakikat, cara kerja, dan manfaat dari dalālah șawtīyah ini, khususnya pada kajian semantik bahasa Arab.

\section{Metode Penelitian}

Penelitian ini menggunakan metode penelitian kualitatif. Pada dasarnya, metode kualitatif dapat digunakan pada ranah aplikasi yang luas. Metode kualitatif adalah metode yang hasil penelitiannya tidak didapatkan melalui teknik statistik atau metode kuantifikasi lainnya. Penelitian kualitatif pada umumnya menggunakan pendekatan naturalistik untuk memahami fenomena tertentu. Penelitian corak kualitatif menjalankan penelitiannya dengan mengumpulkan dasta non-statistik yang kemudian dianalisis dan diinterpretasikan (Anggito \& Setiawan, 2018). Lebih lanjut, metode kualitatif merupakan sebuah konsep penelitian yang datanya dapat diperoleh melalui wawancara, observasi peserta, dan analisis teks atau kajian pustaka. Secara garis besar, penelitian yang menggunakan metode kualitatif memiliki perbedaan dari penelitian kuantitatif pada bentuk datanya. Metode kualitatif datanya tidak berupa angka-angka sebagaimana metode kuantitatif. Tiga sifat atau ciri utama dari metode kualitatif adalah fleksibel, kontekstual, dan deskriptif (Tracy, 2019).

Penelitian ini merupakan penelitian yang berbasis text analysis atau penelitian pustaka. Dalam melaksanakan penelitian ini, peneliti merujuk ke beberapa sumber kepustakaan terkait dengan ilmu 
semantic, khususnya pembahasan tentang makna fonemik (dalälah șawtīyah) dalam kajian semantik Arab. Secara umum, penelitian ini berusaha menafsirkan atau mengintepretasikan peran bunyi dalam proses pemaknaan dalam setiap bagian dari struktur dalam bahasa Arab. Struktur tersebut mulai dari kata, frasa, hingga kalimat. Dalam menjelaskan objek kajiannya, penelitian ini menggunakan perspektif filsafat ilmu dalam membangun kerangka setiap keilmuan, yaitu ontologi, epistemologi, dan aksiologi.

Ontologi merupakan ilmu hakikat yang menyelidiki alam nyata ini dan bagaimana keadaan yang sebenarnya. Ontologi juga dapat berarti ilmu pengetahuan yang meneliti segala sesuatu yang ada (Bahrum, 2013). Kemudian, ontologi juga dapat diartikan sebagai ilmu yang berbicara tentang asal usul dari sesuatu (Iriani et al., 2021). Dari pengertian-pengertian tersebut, dapat disimpulkan bahwa dalam proses penelitian suatu ilmu, ontologi merupakan pembahasan hakikat dari ilmu tersebut. Sebagai contoh, pembahasan ontologi pada penelitian ini merupakan pembahasan tentang hakikat dari makna fonemik (dalālah șawtīyah) dalam bahasa Arab serta kedudukannya dalam ilmu semantik. Adapun epistemologi merupakan pemembahasan mengenai teori sebuah ilmu pengetahuan. Melalui epistemologi, kebenaran ilmiah diberdayakan dalam bentuk sikap dan perilaku dalam rangka validasi kebenaran ilmiah dengan menggunakan metode dan sistem untuk memproduksi sumber daya alam sesuai dengan kebutuhan hidup demi tercapainya tujuan kesejahtraan dan kebahagiaan bagi seluruh umat manusia dengan menghindarkan eksploitasi yang cendrung menguras sumber daya alam dan merusak lingkungan hidup (Khojir, 2011). Secara singkat, dalam pembahasan epistemologi penelitian ini, peneliti mengkaji bagaimana cara kerja atau metode dari dalālah șawtīyah dalam bahasa Arab. sementara itu, aksiologi adalah sebuah ilmu pengetahuan yang menyelediki hakekat nilai pada umumnya ditinjau dari segi kefilsafatan (Rafiqa, 2020). Aksiologi merupakan pembahasan mengenai nilai yang berhubungan dengan fungsi dari pengetahuan yang diperoleh (Bahrum, 2013). Posisi aksiologi pada penelitian ini adalah sebagai pembahas mengenai fungsi atau kegunaan dari dalālah șawtīyab khususnya dalam bahasa Arab.

\section{Hasil Penelitian dan Pembahasan}

\section{A. Ontologi Dalālah Șawtīyah}

Secara umum ilmu semantik (dalālah) adalah ilmu yang mempelajari makna. Semantik mengkaji tentang hubungan bentuk linguistik dan maknanya (Kroeger, 2019). Selain itu, semantik juga diartikan sebuah cabang ilmu yang mengkaji tentang syarat-syarat yang harus dipenuhi oleh sebuah lambang agar dapat memilki makna ('Umar, 1998). Setelah menilik dan menelaah makna dari ilmu semantik, maka pertanyaan yang muncul adalah makna apa yang dipelajari dalam ilmu semantik?

Ilmu semantik dalam mengkaji makna tidak bisa dilepaskan dengan kajian keilmuan lainnya. Dalam menentukan cakupan kajiannya, semantik akan bersinggungan pada aspek-aspek kajian internal bahasa, seperti fonologi, morfologi, dan sintaksis. Beranjak dari keterkaitan semantik dengan kajian internal bahasa lainnya, bisa ditentukan bahwa cakupan kajian semantik secara umum mencakup empat dimensi, yaitu (1) bunyi (dalälah șawtiyah); (2) morofologi (dalālah șinā ìyah/ sarfìyab); (3) gramatika (dalālab ma'nawìyah/ naḅwìab); dan (4) leksikal (dalālab mu jamīyab) ('Umar, 1998; 'Ukāshah, 2011).

Sebagaimana telah disebutkan, fokus kajian penelitian ini adalah aspek bunyi dan maknanya. Bahasa tidak hanya terdiri dari unsur tulisan saja, namun juga terdiri dari unsur bunyi. Bunyi 
merupakan medium dari pengungkapan simbol bahasa yang memuat suatu makna. Dengan begitu, bunyi juga merupakan medium penyampaian makna (Anīs, 1976). Selain itu, bunyi memiliki keterkaitan dengan semua dimensi yang ada pada cakupan ilmu dalālah, karena bunyi merupakan medium pengungkapan bahasa yang meliputi seluruh dimensinya, mulai dari dimensi terkecil hingga dimensi terbesar. Keterkaitan bunyi dalam bahasa tidak hanya sebagai medium saja, akan tetapi juga berperan untuk memberikan makna dalam bahasa. Oleh karena itu, keterkaitan bunyi dengan makna yang disebabkannya ini dalam ilmu dalālah dikenal dengan istilah dalālah șawtīyah.

Dalālah șawtīyah adalah makna yang didapatkan dari tabiat atau karakter beberapa bunyi yang tersusun , dan bunyi-bunyi tersebut memiliki peran pemaknaan dalam sebuah kata (Anīs, 1976; alFākhirī, n.d.). Bunyi-bunyi dalam bahasa dapat menyusun beberapa fonem, morfem, kata, dan kalimat. Jika dilbandingkan dengan dimensi lainnya yang ada dalam ilmu dalälah, Ibn Jinnī dalam kitab al-Khașāiṣ memberikan istilah dalālab lafzìyah dengan sebutan dalālah sawtīyah. Menurutnya, dalālah șawtīyah merupakan dalālah yang paling kuat dibandingkan dalālah șināìyah/șarfíyah dan dalālah ma'nawiyah/naḅwīyah. Hal ini disebabkan karena dengan mengetahui bunyi, maka akan diketahui unsur kata (Hādif, 2009).

\section{B. Epistemologi Dalālah Șawțiyah}

Menurut Ibrāhīm An̄is (1976), kalām terdiri dari kumpulan unsur bunyi atau suara. Bunyi tersebut dapat menyusun sebuah kata atau bagian dari kata, juga dapat menjadi dua kata atau lebih. Contoh seperti kalimat berikut.

$$
\begin{gathered}
\text { قطعت الشجرة بالفأس ليلة أمس } \\
\text { (qața'tu al-shajarah bi-al-fa’s laylatal-ams) } \\
\text { Saya memotong pohon dengan kapak kemarin malam }
\end{gathered}
$$

Dari kalimat tersebut dapat dibagai menjadi beberapa unsur, mulai dari fonem hingga kalimat yang memiliki makna masing-masing. Sebagai contoh bunyi dari fonem $t u$ akan mengandung makna bahwa yang memotong pohon adalah orang pertama (mutakallim) yang berjumlah satu orang. Lain halnya jika bunyi fonem $t u$ diubah dengan bunyi $t a$, maka akan berubah maknanya bahwa yang menjadi pelaku pemotongan pohon adalah orang kedua (mukhätab) yang berjumlah satu orang. Kemudian, jika dilihat dari unsur terbesarnya, yaitu pada level struktur kalimat secara keseluruhan, kalimat tersebut juga akan mengandung makna yang berbeda, tergantung dari intonasi yang mengucapkan kalimat tersebut. Kalimat tersebut bisa bermakna sebuah pernyataan, namun juga bisa bermakna interogatif (istifhām). Contoh tersebut merupakan gambaran secara sederhana bagaimana bunyi bekerja dalam menentukan makna

\section{Bunyi Fonem}

Pada saat mengucapkan suatu kata, manusia akan mengucapkan kata tersebut dengan mulutnya dan mengeluarkan bunyi dari kata tersebut. Bunyi yang terjadi merupakan sebuah tanda suara dari kata itu, bukan tanda tertulis. Dalam sebuah kata, terdapat beberapa bunyi yang terjadi sesuai dengan bunyi huruf yang ada pada kata tersebut. Misal, pada kata جلس terdapat tiga bunyi, yaitu ja-la-sa. Oleh karena itu, dapat dikatakan bahwa kata tersebut mengandung tiga fonem, satuan bunyi terkecil dalam bahasa. 
Fonem merupakan satuan terkecil dari sistem bunyi bahasa yang memiliki kegunaan tersendiri sebagai yang membedakan makna. Perbedaan bunyi salah satu fonem pada kata tertentu dapat mempengaruhi makna yang terjadi pada suatu kata. Pengaruh fonem dalam membedakan makna suatu kata dengan yang lainnya juga dapat diidentifikasi dengan cara membandingkan dua satuan bahasa atau kata yang memiliki kemiripan bunyi. Dalam bahasa Arab, terdapat dua jenis fonem, yaitu fonem vokal yang mencakup bunyi harakat fathah, dammah, kasrah, dan fonem konsonan yang mencakup perbedaan salah satu huruf pada dua kata yang memiliki kemiripan bunyi. (Amrullah, 2016). Contoh dari perbedaan fonem dalam bahasa Arab yang mempengaruhi perbedaan makna adalah sebagai berikut.

\section{a. Fonem Vokal}

Pada kata جنة, misalnya, terdapat tiga jenis fonem vokal yang dapat digunakan pada huruf jīm. Jenis pertama dengan harakat fathạ sehingga berbunyi جَّannah) yang berarti surga.

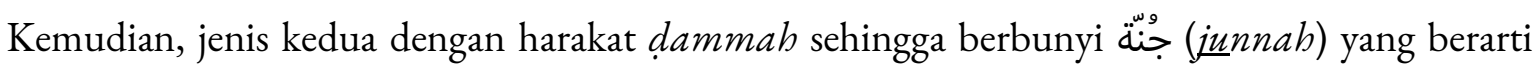
tabir. Sementara itu, jenis yang terakhir dengan harakat kasrab sehingga berbunyi جِّi (jinnah) yang berarti jin (Munawwir, 1997). Dari ketiga kata tersebut, dapat dikatakan bahwa perbedaan fonem vokal pada salah satu huruf dari beberapa kata yang memiliki kemiripan pada kata dasarnya dapat mempengaruhi perbedaan arti dari masing-masing kata.

b. Fonem Konsonan

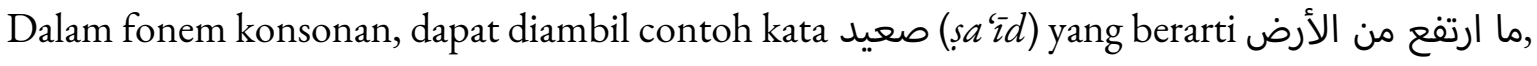
tanah tinggi, dan kata سعيد (sa icd) yang berarti bahagia, untung (Munawwir, 1997). Dua kata tersebut secara penulisan memilki kemiripan pada huruf kedua dan ketiganya. Sebelum ditemukan titik pada penulisan huruf hijaiyah, akan susah membedakan keduanya, karena dua kata tersebut memilki kesamaan bentuk secara penulisannya. Oleh karena itu, untuk membedakan keduanya dapat dilakukan dengan mendengarkan pengucapan dari dua kata tersebut sehingga diketahui makna yang benar dan sesuai dengan keinginan penuturnya, yaitu dengan mengetahui bunyi fonem pertama yang terdapat pada masing-masing dari kedua kata tersebut. Begitupula dengan kata شريعة (sharí'ah) yang berarti syariat, sunnah, hukum, peraturan, dengan kata سريعة (sari'ah) yang berarti cepat (Munawwir, 1997). Jika seseorang penutur lalai dalam pengucapan huruf pertama dari kedua kata tersebut sehingga menimbulkan perbedaan bunyi fonem pertama, maka akan terjadi perubahan makna yang menimbulkan kesalahpahaman dari mitra tutur.

\section{Tekanan (al-Nabr)}

al-nabr merupakan bagian dari fenomena dalälah șawțīyah (Anīs, 1976). Secara bahasa, al-nabr berarti muncul dan tampak (al-burüz wa-al-zubūr). Dari asal kata al-nabrini kemudian muncul kata minbar. Kata minbar dalam bahasa Arab memiliki arti sebuah tempat dalam masjid untuk berkhutbah di mana khatib ketika berdiri di tempat tersebut dapat dilihat oleh para hadirin (Bashar, 2000). Dalam kajian fonologi, al-nabr juga diartikan dengan tekanan (stress). Tekanan adalah aktivitas seluruh organ bunyi dalam waktu yang bersamaan. Ketika sebuah kata diberi tekanan dalam 
pengucapannya, dapat dilihat bahwa seluruh organ bunyi beraktivitas secara penuh, dan semua otot paru-paru mengencang. Begitu pula halnya dengan gerakan dua pita suara, keduanya merengang dan saling mendekat satu sama lain untuk meminimalisir kadar udara yang keluar sehingga frekuensi getaran pun bertambah. Akibat dari proeses tersebut, bunyi yang dihasilkan menjadi kuat dan jelas di pendengaran (Rosyidi, 2016). Selain itu, secara istilah al-nabr juga diartikan dengan sebuah fenomena bunyi di mana potongan kata tertentu diucapkan secara lebih jelas daripada potongan lainnya. al-nabr dalam mempengaruhi makna biasanya terjadi pada kata (kalimah) maupun kalimat (jumlab).(Bashar, 2000)

\section{a. Nabral-Kalimab}

Pada praktiknya, al-nabr dapat mempengaruhi makna dari kata (kalimah) yang diucapkan. Jika seorang penutur mengucapkan kata secara tidak jelas, maka hal tersebut dapat membuat mitra tutur salah dalam memahami perkataannya. Dalam bahasa Arab, pengucapan kata أسد, misalnya, jika penutur memberikan tekanan pada potongan huruf (maqta) pertama, alif, maka kata tersebut berarti seekor Singa. Namun, jika penutur memberikan tekanan pada huruf $d \bar{a} l$, maka kata tersebut berasal dari af'äl tafḍ̂l yang berarti lebih atau benar-benar tertutup ('Ukāshah, 2011). Contoh lainnya, kata ضربا (da-ra-bā) dan ضرب (da-ba). Pada kata yang pertama, penutur akan memberikan tekanan dengan memanjangkan suara $b \bar{a}$ untuk menghadirkan makna bahwa yang memukul berjumlah dua orang, sedangkan pada kata yang kedua, penutur tidak melakukan penekanan pada ba sehingga dapat diketahui bahwa pemukul berjumlah satu orang. Apabila penutur tidak melakukan penekanan ba pada kata yang pertama, namun yang dimaksud dari jumlah pemukul adalah dua orang, maka akan terjadi salah paham di antara penutur dan mitra tutur.

\section{b. Nabral-Jumlah}

Nabr juga terjadi pada kalimat (jumlab). Jika nabr al-kalimab terjadi penekanan bunyi pada salah satu huruf dalam kata, nabr al-jumlab penekanannya terjadi pada salah satu kata pada kalimat. Sebagaimana nabr huruf dalam kata, nabr pada kalimat juga memiliki peran dalam menentukan makna. Contoh seperti kalimat di bawah ini.

$$
\begin{gathered}
\text { هل سافر أخوك أمس؟ } \\
\text { (bal sāfara akbūka ams?) } \\
\text { Apakah saudaramu pergi kemarin? }
\end{gathered}
$$

Jika penanya menekankan pada kata sāfara, dapat dimaknai bahwa penanya meragukan apakah kejadian pergi yang dilakukan oleh suadara dari yang ditanya benar-benar terjadi? Kemudian, apabila penanya me-nabr-kan pada kata akbüka, maka dapat dimaknai bahwa penanya tersebut ragu, siapakah yang sebeneranya pergi, apakah saudara dari yang ditanya atau orang lain yang pergi? (Anīs, 1975).

\section{Intonasi (al-Tanghim)}

Setiap bahasa pasti memiliki nada. Hal tersebut merupakan konsekuensi dari sebuah fakta diproduksinya bahasa yang berasal dari getaran pita suara dengan kecepatan tertentu. Getarangetaran yang terjadi sangatlah berhubungan erat dengan nada yang dirasakan oleh pendengar. 
Semakin tinggi tingkat getaran, maka semakin tinggi pula nada yang dirasakan (Katamba, 1989). Nada dalam sebuah bahasa yang dihasilkan dari getaran-getaran pita suara dapat disebut dengan intonasi. Sebagaimana bahasa lainnya, dalam bahasa Arab juga terdapat nada yang dihasilkan penutur ketika menggunakannya. Intonasi dalam bahasa Arab disebut dengan tanghim atau naghmah kalämīyah. Intonasi merupakan keras dan rendahnya bunyi, seperti halnya nada atau penggunaan musik untuk menyampaikan pesan tertentu kepada mitra tutur yang digunakan pada kalimat atau narasi tertentu (Shūsh, 2020). Tanghìm tidaklah sama dengan nabr. Jika ditilik dari pengertiannya, dapat dibedakan antara nabr dan tanghim, bahwa cakupan tanghim lebih luas daripada nabr (Bashar, 2000).

Tanghim sebagai nada dapat memberikan pemaknaan pada bahasa. Dalam bahasa Cina, misalnya, suatu kata yang memiliki beberapa makna dapat diketahui tiap maknanya dengan intonasi yang digunakan. Dengan kata lain, intonasi dalam bahasa Cina dapat membedakan makna suatu kata yang memilki banyak makna (Anis, 1976). Selain itu, faktanya, kalimat atau pernyataan yang diucapkan manusia tidak akan terlepas dari dari intonasi. Intonasi tentunya memiliki peran yang begitu penting dalam suatu bahasa. Salah satu peran dari yang dimiliki tanghim adalah peran makna kontekstual (wazîfah dalälīyah siyāqīyah). Peran ini dipengaruhi faktor eksternal dari bahasa, yaitu faktor sosial (Bashar, 2000).

Bahasa sebagai sarana komunikasi antarmanusia berperan sebagai pembawa pesan atau makna yang dibawa penutur untuk mitra tuturnya. Dalam pengungkapannya, penutur dipengaruhi faktor emosionalnya seperti perasaan senang, marah, takjub, dan lainnya. Faktor emosional tersebut nantinya dapat memengaruhi bagaimana cara penutur dalam mengungkapkan pesannya. Dalam konteks ini adalah intonasi yang dituturkannya. Jadi, misalnya, intonasi kalimat yang mengandung pertanyaan nantinya akan berbeda dengan kalimat yang mengandung takjub.

Dalam bahasa Arab, sebuah kalimat juga dapat memiliki makna yang berbeda-beda, tergantung dari tanghim yang digunakan penuturnya. Sebuah kalimat dapat bermakna ratapan (tabassur), teguran (zajr), ketidakrelaan ('adam ar-ridá), keterkejutan (dabshab), dan seterusnya. Semua makna yang terkandung dalam sebuah kalimat dapat diidentifikasi dari intonasi yang digunakan. Dengan demikian, intonasi juga memiliki peran yang penting dalam menentukan makna dalam bahasa arab. Contoh seperti frasa يا شيخ (yā shaykh) dalam bahasa Arab dapat diucapkan dengan beberapa intonasi. Intonasi dalam pengucapan tersebut dapat mengandung arti memanggil, bertanya, atau terkejut.

Menurut Kamāl Bashar (2000), dalam bahasa Arab setidaknya terdapat dua corak tanghìm yang bisa digunakan. Masing-masing corak melekat pada karakteristik kalimat (jumlah) tertentu, sehingga kita dapat mengetahui makna dari kalimat yang diucapkan. Corak intonasi tersebut adalah intonasi turun (al-naghmah al-bābițab) dan intonasi naik (al-naghmah al-șàidah). al-naghmah al-häbițah, disebut intonasi turun karena nada intonasi semakin menurun pada akhir kalimat. Corak intonasi ini meliputi, (1) kalimat pernyataan (jumlab taqrïrīyah), seperti contoh محمود في البيت (Mahmūd fi al-bayt), Mahmud di rumah; (2) pertanyaan dengan kata tanya tertentu (jumlah istifhāmīyah bial-adawāt al-khāsșah), seperti fìyn, matá, izzay. Contoh seperti محمود فين؟ (Mahmūd fìyn?), Mahmud dimana?; dan (3) kalimat perintah (jumlah talabiyah), seperti contoh اخرج برد (ukhruj barrab), keluar! 
Selanjutnya, al-naghmah al-șāi idah, disebut intonasi naik karena nada intonasi semakin naik pada akhir kalimat. (Basyar, 2000). Adapun kalimat yang memilki corak intonasi naik, yaitu (1) pertanyaan (jumlah istifhāmìyah) yang harus dijawab dengan "ya" atau "tidak". Contoh seperti (Mahmūd fĩ al-bayt?), Mahmud di rumah?; (2) kalimat yang tergantung (jumlab muallaqah, yaitu kalimat yang tidak lengkap atau yang terkait dengan setelahnya seperti pada jumlah shartīyah. Contoh, إذا جئت، نتفاهم (idhā ji'ta, natafāham), Jika kamu datang, maka kita bisa diskusi. Letak naiknya intonasi ada pada jumlah al-sharț, bukan pada jawāb al-shart.

\section{Aksiologi Dalālah Sawțiyah}

Bahasa, dalam penerapannya, tidak hanya ditulis, namun juga diucapkan. Sebagaimana telah diketahui, bahasa merupakan rangkaian dari bunyi-bunyian yang digunakan untuk mengungkapkan perasaan manusia kepada manusia lainnya. Bunyi-bunyian tersebut merupakan produk dari getarangetaran yang terjadi pada pita suara manusia. Dalam hal ini, makna fonemik (dalālah șawtīyah) memiliki arti penting dalam sebuah bahasa yang diucapkan. Dalālah sawtīyah dalam setiap dimensinya yang meliputi fonem, morfologi, dan gramatikal beserta konteksnya, memilki tugas masing-masing untuk menentukan makna bahasa dalam dimensi-dimensi tersebut.

Bunyi, dalam ranah fonem, berperan sebagai pembeda antara satu kata dengan lainnya yang memiliki kemiripan. Dengan demikian, dapat dibedakan maknanya melalui bunyi salah satu fonemnya. Kemudian, bunyi penekanan pada bagian atau suatu kata dalam sebuah kalimat pada ranah dimensi morfologi dan gramatika, juga dapat menentukan makna apa yang terkandung pada kalimat yang diucapkan. Oleh karena itu, intonasi (tanghim) yang merupakan rangkaian bunyi dalam membentuk nada pada kalimat, dengannya dapat diklasifikasikan jenis kalimat apa yang digunakan oleh penutur, apakah itu pernyataan ataukah pertanyaan, Dengan intonasi, dapat diketahui maksud makna yang terkandung dalam keseluruhan kalimat yang diucapkan oleh penuturnya.

\section{Simpulan}

Bunyi merupakan salah satu unsur utama dalam bahasa. Unsur bunyi tidak bisa dipisahkan dari bahasa mana pun, karena setiap bahasa pastilah bersumber atau hasil produksi dari suara yang dihasilkan oleh getaran-getaran pita suara dari seorang penutur sebuah bahasa. Dengan bunyi, seorang penutur dapat menyampaikan pesan-pesan yang ada di pikirannya, simbol atau lambang bahasa yang awalnya berupa teks kepada mitra tutur melalui pendengarannya. Dengan kata lain, bunyi juga sebagai pembawa pesan atau makna yang terkandung dalam simbol bahasa. Selain itu, bunyi memilki keterkaitan dengan semua dimensi yang ada pada cakupan ilmu dalälah, karena bunyi merupakan medium pengungkapan bahasa yang meliputi seluruh dimensinya, mulai dari dimensi terkecil hingga dimensi yang terbesar Dalam struktur bahasa, bunyi tidak hanya berperan membawa pesan dari ungkapan penutur kepada mitra tutur, namun juga dapat memengaruhi perubahan makna, baik kata, frasa, maupun kalimat. Adapun metode atau cara kerja bunyi dalam memberikan pemaknaan pada bahasa Arab dapat berupa perbedaan bunyi fonem, tekanan bunyi (al-nabr) pada suku kata atau kata, juga intonasi (al-tanghim) yang terjadi pada suatu frase atau kalimat. Dengan demikian, jelas bahwa fungsi bunyi memiliki peran dalam perubahan makna. 
Tidaklah mengherankan jika dalam kajian ilmu dalālah, pembahasan ini disebut dengan dalālah sawtīyah.

\section{Daftar Rujukan}

Amrullah, M. A. (2016). Fonologi bahasa Arab: Tinjauan deskriptif fonem bahasa Arab. Jurnal Al Bayan: Jurnal Jurusan Pendidikan Babasa Arab, 8(1), 1-13. doi:10.24042/albayan.v8i1.353

Anggito, A., \& Setiawan, J. (2018). Metodologi penelitian kualitatif. Sukabumi: CV Jejak.

Anīs, I. (1975). al-Așwāt al-lughawìyah. Cairo: al-Maktabat al-Anjlū al-Miṣrīyah.

Anīs, I. (1976). Dalālat al-alfāz. Cairo: al-Maktabat al-Anjlū al-Mișrīyah.

Bahrum. (2013). Ontologi, epistimologi, aksiologi. Sulesana:Jurnal Wawasan Keislaman, 8(2), 3545. doi:10.24252/.v8i2.1276

Bashar, K. (2000). 'Ilm al-Așwāt. Cairo: Dar Gharīb.

Fromkin, V., Rodman, R., \& Hyams, N. (2017). An introduction to language, (11 ${ }^{\text {th }}$ ed.). Boston: Cengange Learning Inc.

al-Fākhirī, Ș. S. A. (n.d.). al-Dalālah al-șawtīyah fì al-lughah al-'Arabiyah. Alexandria: al-Maktab al-'Arabī al-Hadīth.

Hādif, B. S. (2009). al-Dalālah al-ṣawțīyah 'inda Ibn Jinnī min khilāl kitabih al-Khașā’iṣ. Majallat Hawliyāt al-Turāth, 9, 141-162. Retrieved from https://annales.univmosta.dz/index.php/180.html

Ibn Jinnī. (1952). al-Khaṣā’ iṣ (2 ${ }^{\text {nd }}$ ed.). Dār al-Kitāb al-'Arabī.

Iriani, D., Tuharyati, Y., Roihanah, R., \& Utami, N. S. (2021). The relevance of philosophy of science and ethical politics in guarding the integrity of election. The Indonesian Journal of Legal Thought (IJELTH), 1(1), 26-42. doi:10.23917/ijleth.v1i1.12677

Katamba, F. (1989). An introduction to phonology. Harlow, United Kingdom: Longman.

Khojir. (2011). Membangun paradigma ilmu pendidikan Islam: Kajian ontologi, epistemologi dan aksiologi. Dinamika Ilmu: Jurnal Pendidikan, 11(1), 1-13. doi:10.21093/di.v11i1.51

Kroeger, P. (2019). Analyzing meaning: An introduction to semantics and pragmatics. Berlin: Language Science Press.

Munawwir, A. W. (1997). Al-Munawwir: Kamus Arab-Indonesia. Yogyakarta: Penerbit Pustaka Progressif.

Rafiqa, S. (2020). Ideology in the Indonesian President's speech: Study in the dimension of ontology, epistemoligy, and axiology. In U. Kusmawan, S. Aisyah, I. Rokhiyah, Andayani, D. R. Jovanka, \& D. Sukmayadi (Eds.), Emerging perspective and trends in innovative technology for quality education 4.0 (pp. 1-4). London: Taylor \& Francis Group.

Rosyidi, A. W. (2016). Penerapan pola nabr dan tanghim dalam maharah al kalam mahasiswa Indonesia. LiNGUA, 11(1), 45-53. oi:10.18860/ling.v11i1.3438

Shūsh, M. 'A. M. (2020). Zawāhir al-dalālah al-ṣawtīyah wa-tadrīsuhā li-ghayr al-nāṭiqīna bi-al'Arabīyah. Majallat al-Tawāsulīyah, 6(17), 95-122. Retrieved from https://www.asjp.cerist.dz/en/article/133376

Tracy, S. J. (2019). Qualitative research methods: Collecting evidence, crafting analysis, communicating impact ( $2^{\text {nd }}$ ed.). New Jersey: Wiley Blackwell. 
'Ukāshah, M. (2011). al-Taḥlīl al-lughawi fì daw'i 'ilm al-dalālah: Dirāsah fì al-dalālah alsawtīyah, wa-al-șarfíyah, wa-al-naḅwīyah, wa-al-mu'jamīyah. Cairo: Dar al-Nashr li-alJāmi'āt.

'Umar, A. M. (1998). Ilmu al-Dalālah. Cairo: 'Ālam al-Kutub. 